\title{
CHARACTERIZATION OF CHILDREN'S CONSUMPTION OF CHICKEN AND TURKEY MEAT TO DEVELOP SOCIAL RESPONSIBILITY STRATEGIES
}

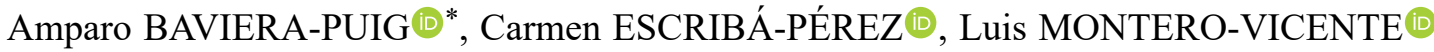 \\ Department of Economics and Social Sciences, Faculty of Business Administration and Management, \\ Universitat Politècnica de València, Camino de Vera s/n, 46022 Valencia, Spain
}

Received 26 February 2021; accepted 1 April 2021

\begin{abstract}
Purpose - to analyze the image, consumption and purchase habits of chicken and turkey meats by households with children as both kinds of meat are healthier than others.

Research methodology - in the field of marketing, we carried out a telephone survey, a tool commonly used in market research to obtain primary source information.

Findings - there are differences between households with and without children under 18 years old in the consumption and purchase habits of turkey and chicken meat. Instead, there is no difference in the image of both meats between the total of the sample and the households with children under 18 years old.

Research limitations - we have not analysed the performance of these meats in relation to other types of meat. Therefore, it would be useful to have data on other meats in the future in order to make comparisons.

Practical implications - the results of the research can be used to develop appropriate social responsibility strategies in the meat industry.

Originality/Value - the point of view we provide is novel as we have not found comparable studies for these types of meat. Previously, the authors have analysed the children's consumption of rabbit meat using a similar approach.
\end{abstract}

Keywords: turkey meat, chicken meat, children, consumption habits, image, purchase habits, frequency of purchase.

JEL Classification: L66, M14, Q13.

Conference topic: Contemporary Organizations Development Management.

\section{Introduction}

Consumers are becoming increasingly informed about how food is produced and want to know more about how animals are raised on farms and how they are processed into food in the meat industry (Montero \& Baquero, 2016). How to face this demand is a challenge for farmers and agribusiness actors. Corporate Social Responsibility (CSR) presents a leading channel for them in order to discharge their ethical responsibilities (de Olde \& Valentinov, 2019). Specifically, producers and retailers are progressively engaging in CSR initiatives to show their commitment to sustainability issues such as animal welfare and environment. Farmers are also increasing their efforts to monitor and report on the impact of their production on a wide range of sustainability issues (Reis \& Molento, 2020). However, these are not the only opportunities that these actors have from a CSR point of view.

When buying food, consumers search products that are differentiated by unique attributes. Traditionally, price and brand have been perceived as the key attributes. Instead, due to the evolution of the consumer habits, there were new food attributes and claims, such as the signs of quality (for example, the protected designation of origin) and information on organic origin. Currently, consumers focus on newer attributes which include fair trade, low carbon footprint (CF), natural, biodynamic, animal welfare and indicators for sustainable and healthy consumption (Burnier et al., 2020; Grunert et al., 2004). The consumers perceive all these attributes in different ways, taking into account the image of the brand or of the product. In other words, brand image is the way the product/brand is defined by consumers based on important attributes. The image can help us better understand consumer behaviour towards a product (Montero-Vicente et al., 2018).

\footnotetext{
*E-mail: ambapui@upv.es
} 
In this research, we focus on the meat sector. Meat is an important source of protein, essential amino acids, B vitamins, minerals and other bioactive compounds (Martini et al., 2019). Meat consumption is highly recommended, as it favours development of body and cognitive functions in children and adolescents, as well as in babies (Cofnas, 2019; Tang et al., 2018). Specifically, chicken and turkey are recommended due to its nutritional and dietary properties as they are lighter than other meats (Pereira \& Vicente, 2013). Previous studies show that, commercially, chicken meat has a similar positioning to turkey meat (Montero-Vicente et al., 2018). So, in the mind of the consumers both types are perceived as healthy and low-fat meats. Due to these characteristics, their consumption is ideal for children.

An in-depth analysis of this market segment may provide new opportunities to the meat sector to develop social responsibility strategies due to the many significant risks and criticisms that it faces (health improvement, the threat of vegetarian and animal movements, animal welfare...) (Maloni \& Brown, 2006). From a healthy point of view, these types of meat can offer new opportunities to the sector. However, there is hardly any research on the consumption and image of both meats in children.

So, the purpose of the article is threefold: i) to analyze the consumption and purchase habits of chicken and turkey meats by households with children as both kinds of meat are healthier than others; ii) to analyze the image of chicken and turkey meat in the total of the sample and in the households with children to check if there are differences between them; and iii) to propose social responsibility strategies that could be developed in the meat industry according to the results obtained.

The paper is structured as follows. First, material and methods are explained. Then, we present the results obtained. Next, we discuss them in order to offer new insights to the meat sector to develop new CSR strategies and, finally, the conclusions are drawn.

\section{Materials and methods}

To obtain information from primary sources, we used the methodology of marketing research. A telephone survey was carried out in peninsular Spain, in other words, throughout the Spanish mainland, excluding the Balearic Islands, Canary Isles, Ceuta and Melilla. The interview was by telephone and held using a CATI (Computer Assisted Telephone Interview) system. The telephone numbers were selected at random from public telephone directories. The fieldwork was carried out in May and June 2018.

The sample size was 625 interviews, for an error of $\pm 4.0 \%$ and a confidence level of $95.5 \%$. The percentages of population with (p) and without the feature studied (q) were considered 0.5 . The error was below the desirable limit of $4 \%$ indicated by Cea (2010) in social research. The selected consumer profile is in charge of food purchasing or shares this responsibility in households where chicken and turkey meat is consumed, even sporadically. The interviewees' ages ranged from 18 to 75 years.

We performed different statistical analysis. On one side, we used frequency distributions to describe the data obtained in the survey. On the other side, we calculated cross-tabulations to differentiate the different types of households analysed. We compared the sample total and those households with and without children under 18 years old. We used the chi square as significance statistical test.

\section{Results}

\subsection{Sample profile}

Table 1 shows the sample characteristics. From the total sample, 29.6\% are households with children under 18 years old. There were only significant differences for "age" and "household size" variables. In both types of households (with and without children), the woman is usually responsible for purchasing. In households with children under 18 years old, the age of the person responsible for purchasing is between 25 and $44(73.51 \%)$, while in households without children under 18 years old the age ranges from 35 and 64 (63.4\%). Households with children under 18 years old are concentrated in East and North-Central (15.14\% each area) and Centre (14.05\%). Instead, households without children under 18 years old are concentrated in Centre (15.00\%), Madrid (14.09\%) and North-west (13.86\%). In both cases, the person responsible of the purchase mainly has formal education (FP2 - Secondary education and higher education) (71.35\% in households with children under 18 years old and $62.87 \%$ in households without children under 18 years old). There are not significant differences for the residential habitat between both types of households. The size of households is key when describing them, as homes with children under 18 years old have three to five members $(90.77 \%)$, and those without children under 18 years old have two to three members $(64.77 \%)$. 
A. Baviera-Puig, C. Escribá-Pérez, L. Montero-Vicente. 2021. Characterization of children's consumption of chicken and turkey meat to develop social responsibility strategies

Table 1. Profile of the total sample and households with and without children under $18 \mathrm{yr}$ old (source: own elaboration)

\begin{tabular}{|c|c|c|c|c|c|c|}
\hline \multirow{2}{*}{ Variable } & \multicolumn{2}{|c|}{$\begin{array}{l}\text { Sample total } \\
\quad(\mathrm{n}=625)\end{array}$} & \multicolumn{2}{|c|}{$\begin{array}{c}\text { Homes with children less than } \\
18 \text { yr old }(\mathrm{n}=185)\end{array}$} & \multicolumn{2}{|c|}{$\begin{array}{l}\text { Homes without children less } \\
\text { than } 18 \text { yr old }(n=440)\end{array}$} \\
\hline & Frequency & $\%$ & Frequency & $\%$ & Frequency & $\%$ \\
\hline \multicolumn{7}{|c|}{$\operatorname{Sex}$} \\
\hline Male & 184 & 29.44 & 57 & 30.81 & 127 & 28.86 \\
\hline Female & 441 & 70.56 & 128 & 69.19 & 313 & 71.14 \\
\hline \multicolumn{7}{|c|}{$A g e^{* *}$} \\
\hline Less than 18 yr old & 48 & 7.68 & 8 & 4.32 & 40 & 9.09 \\
\hline 18 to $24 \mathrm{yr}$ & 108 & 17.28 & 27 & 14.59 & 81 & 18.41 \\
\hline 25 to $34 \mathrm{yr}$ & 121 & 19.36 & 81 & 43.78 & 40 & 9.09 \\
\hline 35 to $44 \mathrm{yr}$ & 135 & 21.60 & 55 & 29.73 & 80 & 18.18 \\
\hline 45 to $54 \mathrm{yr}$ & 135 & 21.60 & 8 & 4.32 & 127 & 28.86 \\
\hline 55 to $64 \mathrm{yr}$ & 78 & 12.48 & 6 & 3.24 & 72 & 16.36 \\
\hline 65 to $75 \mathrm{yr}$ & 0 & 0.00 & 0 & 0.00 & 0 & 0.00 \\
\hline Over $75 \mathrm{yr}$ & 0 & 0.00 & 0 & 0.00 & 0 & 0.00 \\
\hline \multicolumn{7}{|c|}{ Geographic areas } \\
\hline North-east & 78 & 12.48 & 23 & 12.43 & 55 & 12.50 \\
\hline East & 69 & 11.04 & 28 & 15.14 & 41 & 9.32 \\
\hline South & 65 & 10.40 & 20 & 10.81 & 45 & 10.23 \\
\hline Centre & 92 & 14.72 & 26 & 14.05 & 66 & 15.00 \\
\hline North-west & 78 & 12.48 & 17 & 9.19 & 61 & 13.86 \\
\hline North-central & 87 & 13.92 & 28 & 15.14 & 59 & 13.41 \\
\hline Madrid & 85 & 13.60 & 23 & 12.43 & 62 & 14.09 \\
\hline Barcelona & 71 & 11.36 & 20 & 10.81 & 51 & 11.59 \\
\hline \multicolumn{7}{|c|}{ Studies } \\
\hline No studies & 12 & 1.92 & 1 & 0.54 & 11 & 2.51 \\
\hline Primary & 121 & 19.39 & 30 & 16.22 & 91 & 20.73 \\
\hline FP1 - Secondary education & 83 & 13.30 & 22 & 11.89 & 61 & 13.90 \\
\hline FP2 - Secondary education & 147 & 23.56 & 46 & 24.86 & 101 & 23.01 \\
\hline Higher education & 261 & 41.83 & 86 & 46.49 & 175 & 39.86 \\
\hline \multicolumn{7}{|c|}{ Residence habitat } \\
\hline$<10,000$ inhabitants & 98 & 16.50 & 32 & 17.88 & 66 & 15.90 \\
\hline 10,001 to 50,000 inhabitants & 134 & 22.56 & 46 & 25.70 & 88 & 21.20 \\
\hline 50,001 to 100,000 inhabitants & 100 & 16.84 & 27 & 15.08 & 73 & 17.59 \\
\hline 100,001 to 500,000 inhabitants & 141 & 23.74 & 43 & 24.02 & 98 & 23.61 \\
\hline$>500,000$ inhabitants & 121 & 20.37 & 31 & 17.32 & 90 & 21.69 \\
\hline \multicolumn{7}{|c|}{ Household size** } \\
\hline Interviewee only & 40 & 6.41 & 2 & 1.09 & 38 & 8.64 \\
\hline Two & 184 & 29.49 & 4 & 2.17 & 180 & 40.91 \\
\hline Three & 159 & 25.48 & 54 & 29.35 & 105 & 23.86 \\
\hline Four & 191 & 30.61 & 94 & 51.09 & 97 & 22.05 \\
\hline Five & 35 & 5.61 & 19 & 10.33 & 16 & 3.64 \\
\hline$>$ five & 15 & 2.40 & 11 & 5.98 & 4 & 0.91 \\
\hline
\end{tabular}

Note: * Significant at 5\%; ** Significant at 1\%. FP2 = Vocational Education and Training (VET); FP1 = a basic VET available in Spain.

\subsection{Child consumption analysis}

In the total of the sample, we found out that $75.52 \%$ consume turkey meat and $98.72 \%$ consume chicken meat. In the households with children under 18 years old, these percentages are very similar. In particular, $77.84 \%$ consume turkey meat and this value reaches $96.22 \%$ for chicken meat (Table 2). 
Table 2. Consumption of turkey and chicken meats (source: own elaboration)

\begin{tabular}{|c|c|c|c|c|c|c|c|c|}
\hline \multirow{3}{*}{ Variable } & \multicolumn{4}{|c|}{ Sample total } & \multicolumn{3}{c|}{ Homes with children less than 18 yr old } \\
\cline { 2 - 10 } & \multicolumn{2}{|c|}{ Turkey } & \multicolumn{2}{c|}{ Chicken } & \multicolumn{2}{c|}{ Turkey } & \multicolumn{3}{c|}{ Chicken } \\
\cline { 2 - 10 } & Frequency & $\%$ & Frequency & $\%$ & Frequency & $\%$ & Frequency & $\%$ \\
\hline Yes & 472 & 75.52 & 617 & 98.72 & 144 & 77.84 & 178 & 96.22 \\
\hline No & 153 & 24.48 & 8 & 1.28 & 41 & 22.16 & 7 & 3.78 \\
\hline Total & 625 & 100.00 & 625 & 100.00 & 185 & 100.00 & 185 & 100.00 \\
\hline
\end{tabular}

When analyzing the frequency of consumption, we distinguished between fresh and processed meat. We only found significant differences between households with and without children under 18 years old for processed turkey meat (Table 3). In this case, $49.65 \%$ of households with children under 18 years old consume processed turkey meat once a week or more frequently, $23.78 \%$ every two weeks and $16.78 \%$ once a month. In contrast, $63.64 \%$ of households without children under 18 years old consume processed turkey meat once a week or more frequently, $14.91 \%$ every two weeks and $10.55 \%$ once a month.

Table 3. Frequency of consumption of processed turkey meat (source: own elaboration)

\begin{tabular}{|c|c|c|c|c|c|c|}
\hline \multirow{2}{*}{ Variable } & \multicolumn{2}{|c|}{ Sample total } & \multicolumn{2}{|c|}{$\begin{array}{l}\text { Homes with children less } \\
\text { than } 18 \mathrm{yr} \text { old }\end{array}$} & \multicolumn{2}{|c|}{$\begin{array}{l}\text { Homes without children } \\
\text { less than } 18 \text { yr old }\end{array}$} \\
\hline & Frequency & $\%$ & Frequency & $\%$ & Frequency & $\%$ \\
\hline Once a week or more frequently & 246 & 58.85 & 71 & 49.65 & 175 & 63.64 \\
\hline Every two weeks & 75 & 17.94 & 34 & 23.78 & 41 & 14.91 \\
\hline Once a month & 53 & 12.68 & 24 & 16.78 & 29 & 10.55 \\
\hline Once every two months & 24 & 5.74 & 6 & 4.20 & 18 & 6.55 \\
\hline Less than once every two months & 14 & 3.35 & 7 & 4.90 & 7 & 2.55 \\
\hline Never & 6 & 1.44 & 1 & 0.70 & 5 & 1.82 \\
\hline Total & 418 & 100.00 & 143 & 100.00 & 275 & 100.00 \\
\hline
\end{tabular}

Note: Chi square with 5 degrees of freedom $=13.4125(\mathrm{p}=0.0198)$.

\subsection{Frequency of purchase analysis}

When analyzing the frequency of purchase, we distinguished again between fresh and processed meat. This time we found significant differences in all cases except for fresh chicken meat. In the case of fresh turkey meat (Table 4), it is purchased more frequently in households where there are children under 18 years old. $44.32 \%$ of households with children under 18 years old purchase fresh turkey meat once a week or more frequently, 13.51\% purchase it every two weeks and $15.14 \%$ once a month. $17.30 \%$ of households with children under 18 years old never purchase fresh turkey meat. This last percentage rises to $27.50 \%$ for households without children under 18 years old. $34.55 \%$ of households without children under 18 years old purchase fresh turkey meat once a week or more frequently, $14.77 \%$ purchase it every two weeks and $10.68 \%$ once a month.

Table 4. Frequency of purchase of fresh turkey meat (source: own elaboration)

\begin{tabular}{|l|c|c|c|c|c|c|}
\hline \multirow{2}{*}{ Variable } & \multicolumn{2}{|c|}{ Sample total } & \multicolumn{2}{c|}{$\begin{array}{c}\text { Homes with children less } \\
\text { than } 18 \text { yr old }\end{array}$} & $\begin{array}{c}\text { Homes without children less } \\
\text { than } 18 \text { yr old }\end{array}$ \\
\cline { 2 - 8 } & Frequency & $\%$ & Frequency & $\%$ & Frequency & $\%$ \\
\hline Once a week or more frequently & 234 & 37.44 & 82 & 44.32 & 152 & 34.55 \\
\hline Every two weeks & 90 & 14.40 & 25 & 13.51 & 65 & 14.77 \\
\hline Once a month & 75 & 12.00 & 28 & 15.14 & 47 & 10.68 \\
\hline Once every two months & 35 & 5.60 & 9 & 4.86 & 26 & 5.91 \\
\hline Less than once every two months & 38 & 6.08 & 9 & 4.86 & 29 & 6.59 \\
\hline Never & 153 & 24.48 & 32 & 17.30 & 121 & 27.50 \\
\hline Total & 625 & 100.00 & 185 & 100.00 & 440 & 100.00 \\
\hline
\end{tabular}

Note: Chi square with 5 degrees of freedom $=12.0522(\mathrm{p}=0.0341)$. 


\section{A. Baviera-Puig, C. Escribá-Pérez, L. Montero-Vicente. 2021. Characterization of children's consumption of chicken and turkey meat to develop social responsibility strategies}

The frequency of purchase of processed turkey meat is also higher in households with children under 18 years of age (Table 5). $37.30 \%$ of households with children under 18 years old purchase processed turkey meat once a week or more frequently, $16.22 \%$ purchase it every two weeks and $17.84 \%$ once a month. $22.16 \%$ of households with children under 18 years old never purchase processed turkey meat. This last percentage rises to $37.50 \%$ for households without children under 18 years old. $31.36 \%$ of households without children under 18 years old purchase processed turkey meat once a week or more frequently, $14.32 \%$ purchase it every two weeks and $9.77 \%$ once a month.

Table 5. Frequency of purchase of processed turkey meat (source: own elaboration)

\begin{tabular}{|l|c|c|c|c|c|c|}
\hline \multirow{2}{*}{ Variable } & \multicolumn{2}{|c|}{ Sample total } & \multicolumn{2}{c|}{$\begin{array}{c}\text { Homes with children less } \\
\text { than } 18 \text { yr old }\end{array}$} & $\begin{array}{c}\text { Homes without children less } \\
\text { than } 18 \text { yr old }\end{array}$ \\
\cline { 2 - 8 } & Frequency & $\%$ & Frequency & $\%$ & Frequency & $\%$ \\
\hline Once a week or more frequently & 207 & 33.12 & 69 & 37.30 & 138 & 31.36 \\
\hline Every two weeks & 93 & 14.88 & 30 & 16.22 & 63 & 14.32 \\
\hline Once a month & 76 & 12.16 & 33 & 17.84 & 43 & 9.77 \\
\hline Once every two months & 21 & 3.36 & 5 & 2.70 & 16 & 3.64 \\
\hline Less than once every two months & 22 & 3.52 & 7 & 3.78 & 15 & 3.41 \\
\hline Never & 206 & 32.96 & 41 & 22.16 & 165 & 37.50 \\
\hline Total & 625 & 100.00 & 185 & 100.00 & 440 & 100.00 \\
\hline
\end{tabular}

Note: Chi square with 5 degrees of freedom $=18.3522(\mathrm{p}=0.0025)$.

In the processed chicken meat (Table 6), it is also purchased more frequently in households where there are children under 18 years old. $36.76 \%$ of households with children under 18 years old purchase processed chicken meat once a week or more frequently, $20 \%$ purchase it every two weeks and $14.59 \%$ once a month. $20.54 \%$ of households with children under 18 years old never purchase processed chicken meat. This last percentage rises to $47.73 \%$ for households without children under 18 years old. $24.77 \%$ of households without children under 18 years old purchase processed chicken meat once a week or more frequently, $11.36 \%$ purchase it every two weeks and $10.68 \%$ once a month.

Table 6. Frequency of purchase of processed chicken meat (source: own elaboration)

\begin{tabular}{|l|c|c|c|c|c|c|}
\hline \multirow{2}{*}{ Variable } & \multicolumn{2}{|c|}{ Sample total } & \multicolumn{2}{c|}{$\begin{array}{c}\text { Homes with children less } \\
\text { than } 18 \text { yr old }\end{array}$} & \multicolumn{2}{c|}{$\begin{array}{c}\text { Homes without children less } \\
\text { than } 18 \text { yr old }\end{array}$} \\
\cline { 2 - 7 } & Frequency & $\%$ & Frequency & $\%$ & Frequency & $\%$ \\
\hline Once a week or more frequently & 177 & 28.32 & 68 & 36.76 & 109 & 24.77 \\
\hline Every two weeks & 87 & 13.92 & 37 & 20.00 & 50 & 11.36 \\
\hline Once a month & 74 & 11.84 & 27 & 14.59 & 47 & 10.68 \\
\hline Once every two months & 19 & 3.04 & 8 & 4.32 & 11 & 2.50 \\
\hline Less than once every two months & 20 & 3.20 & 7 & 3.78 & 13 & 2.95 \\
\hline Never & 248 & 39.68 & 38 & 20.54 & 210 & 47.73 \\
\hline Total & 625 & 100.00 & 185 & 100.00 & 440 & 100.00 \\
\hline
\end{tabular}

Note: Chi square with 5 degrees of freedom $=41.2329(\mathrm{p}=0.0000)$.

\subsection{Opportunities for turkey and chicken meats among children}

Table 7 shows the presentations proposed for children for both types of meat. In the case of turkey meat, consumers propose burgers $(21.88 \%)$, nuggets $(21.61 \%)$, sliced cold cuts $(11.91 \%)$, sausages $(10.53 \%)$, skewers $(9.14 \%)$ and croquettes $(8.31 \%)$. The rest of responses did not reach $5 \%$ of the total of frequencies. The chicken meat presentations proposed for children are the same but in different order: burgers $(21.74 \%)$, nuggets $(20.97 \%)$, skewers $(10.74 \%)$, croquettes $(10.23 \%)$, sausages $(9.46 \%)$, and sliced cold cuts $(7.42 \%)$. The most favourite presentations for both types of meat are burgers and nuggets. 
A. Baviera-Puig, C. Escribá-Pérez, L. Montero-Vicente. 2021. Characterization of children's consumption of chicken and turkey meat to develop social responsibility strategies

Table 7. Types of meat presentations proposed for children (source: own elaboration)

\begin{tabular}{|l|c|c|c|c|c|c|}
\hline \multirow{2}{*}{ Variable } & \multicolumn{3}{|c|}{ Turkey } & \multicolumn{3}{c|}{ Chicken } \\
\cline { 2 - 7 } & Frequency & Total \% & Sample \% & Frequency & Total \% & Sample \% \\
\hline Burger & 79 & 21.88 & 42.70 & 85 & 21.74 & 46.20 \\
\hline Skewers & 33 & 9.14 & 17.84 & 42 & 10.74 & 22.83 \\
\hline Nuggets & 78 & 21.61 & 42.16 & 82 & 20.97 & 44.57 \\
\hline Croquettes & 30 & 8.31 & 16.22 & 40 & 10.23 & 21.74 \\
\hline Sausages & 38 & 10.53 & 20.54 & 37 & 9.46 & 20.11 \\
\hline Sliced cold cuts & 43 & 11.91 & 23.24 & 29 & 7.42 & 15.76 \\
\hline Iron, breaded,... & 15 & 4.16 & 8.11 & 17 & 4.35 & 9.24 \\
\hline In fillets & 6 & 1.66 & 3.24 & 6 & 1.53 & 3.26 \\
\hline Wings & 1 & 0.28 & 0.54 & 3 & 0.77 & 1.63 \\
\hline In strips / dice /chopped & 2 & 0.55 & 1.08 & 3 & 0.77 & 1.63 \\
\hline Just like adults & 3 & 0.83 & 1.62 & 16 & 4.09 & 8.70 \\
\hline Others & 17 & 4.71 & 9.19 & 13 & 3.32 & 7.07 \\
\hline DK / DA & 16 & 4.43 & 8.65 & 18 & 4.60 & 9.78 \\
\hline Total & 361 & 100.00 & 195.14 & 391 & 100.00 & 212.50 \\
\hline
\end{tabular}

Note: DK / DA = Do not know / Do not answer.

\subsection{Image of turkey and chicken meats}

If we analyze the image of both meats in the total of the sample and in households with children under 18 years old with respect to several items, we obtain similar results (Figures 1 and 2). In all items the value of chicken is higher except for "It is a healthy and wholesome meat" and "It is a high quality meat". Chicken excels in the following items: "It is easy to find in the shops where I do my shopping", "It has a good quality-price ratio", "It is a tasty meat", "It is an easy and quick meat to cook", "It can be prepared in many ways" and "It is a meat with an attractive price, economic".

The only difference between both groups is the item "It is digestive, not heavy". In the total of sample, chicken $(83.84 \%)$ has a higher value than turkey meat $(81.44 \%)$, while in the households with children under 18 years old the turkey $(87.03 \%)$ obtains a higher value than chicken meat $(83.24 \%)$. Although the pattern is different, the percentages are very similar.

\section{Discussion}

The aim of this research consists of analyzing the image, consumption and purchase habits of chicken and turkey meats by households with children as both kinds of meat are healthier than others. When analyzing the frequency of consumption, we found significant differences between households with and without children under 18 years old for processed turkey. Purchases of processed chicken and turkey meats are more frequent in households with children under 18 years of age, especially for chicken meat. In the case of fresh turkey meat, it is purchased more frequently in households where there are children under 18 years old. So, we can see that households with children under 18 years old prefer these types of meat in comparison with those households where there are not children. Therefore, the presence of children in the household leads to different meat consumption and purchase habits (Escribá-Pérez et al., 2019).

The favourite presentations for both types of meat are burgers and nuggets. The majority of the meat presentations proposed for children are for processed products. This kind of products have several commercial advantages, as they are characterised by a longer shelf life and high quality and food safety standards as pointed out by Escribá-Pérez et al. (2019). Furthermore, they are convenience products ready to cook or ready to eat. These products are very appropriate to facilitate meal preparation and for managing the diet at home due to the current consumption and working habits (Dalle Zotte, 2002; Petraci \& Cavani, 2013).

The development of functional meat products focused on children also offers new opportunities. Several attractive meat-based bioactive compounds, such as carnosine, anserine, L-carnitine, conjugated linoleic acid, have been studied (Arihara, 2006). Emphasizing these activities is one possible approach for improving the health image of meat and developing functional meat products for children such as meat enriched with omega-3 or calcium along other benefits that are being discovered as well for adults (Agrawal, 2005).

In the analysis of the image of both types of meat, we can conclude that there is no difference in the image between the total of the sample and the households with children under 18 years old. Turkey meat receives higher values for "It is a healthy and wholesome meat" and "It is a high quality meat". However, chicken is perceived as easier to find, easier and quicker to cook, cheaper and with a good quality-price ratio. Similar results were obtained by Montero-Vicente et al. (2018). 


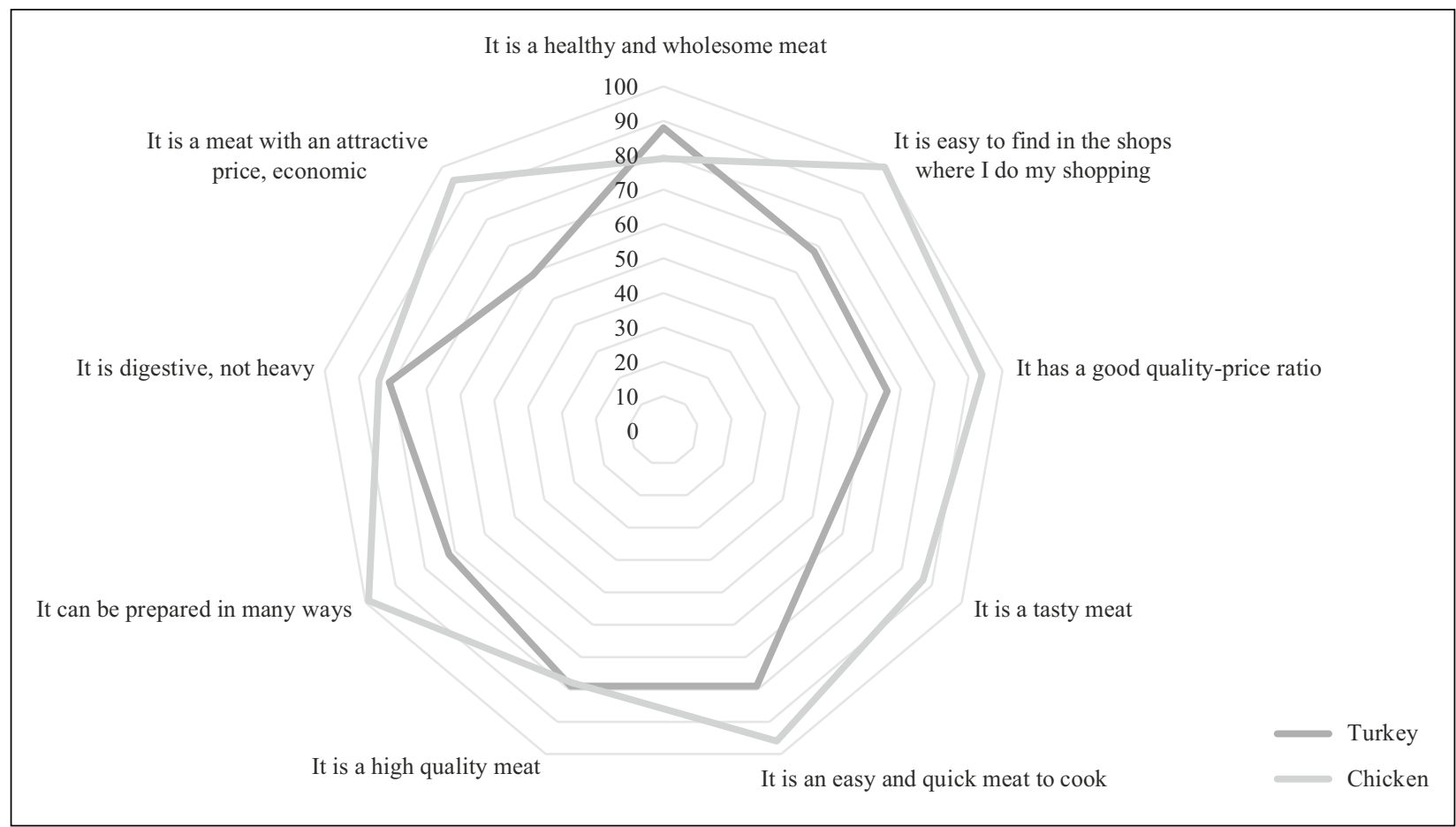

Figure 1. Image of turkey and chicken meats in the total of the sample (\%) (source: own elaboration)

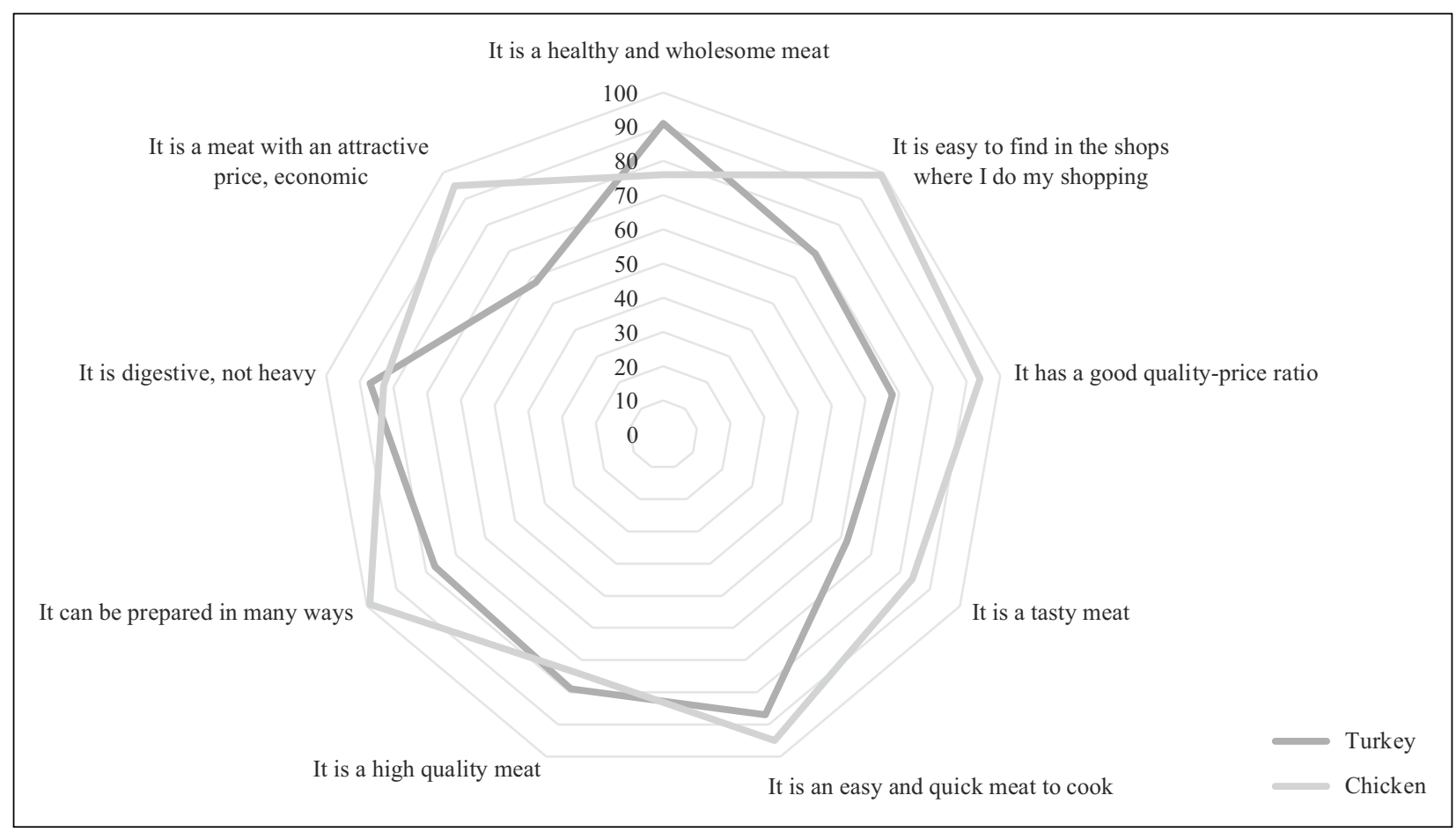

Figure 2. Image of turkey and chicken meats in homes with children less than $18 \mathrm{yr}$ old (\%) (source: own elaboration)

In this scenario, the results of the research can be used to develop social responsibility strategies in the companies or in the sector. Investment in CSR promotes product differentiation at the product and firm levels (McWilliams \& Siegel, 2000). The objective is to produce goods and services with attributes that signal to the consumer that the company/sector is concerned about children's health. The social responsibility strategies that could be developed are based on 3 axes: a) Promoting the meat with a poorer image compared to the other, as both are healthy; b) Encourage children's consumption of both meats; c) Promote a healthy lifestyle among children. This is a key question for the companies in the meat sector as the food industry (in general) faces many significant risks from public criticism of CSR issues in the supply chain (Maloni \& Brown, 2006). 


\section{A. Baviera-Puig, C. Escribá-Pérez, L. Montero-Vicente. 2021. Characterization of children's consumption of chicken and turkey meat to develop social responsibility strategies}

In any of the 3 strategies proposed, a good marketing strategy would be crucial (Buitrago-Vera et al., 2016; Fonti-Furnols \& Guerrero, 2014). On one side, different products adapted to children's necessities and to our current consumption lifestyle could be designed and offered to the market (Buckley et al., 2007; Grunert et al., 2004). On the other side, it would also be necessary to set out the appropriate communication strategy with messages adapted to the specific characteristics of the children (Cooke \& Wardle, 2005; Ilicic et al., 2018). The communication strategy should also be focused on parents due to their important role in feeding their children (Escribá-Pérez et al., 2019).

One limitation of this study is that we have not analysed the performance of these meats in relation to other types of meat (beef, pork, lamb, rabbit...) as in other studies (Escriba-Perez et al., 2017). Therefore, in the future, it would be useful to have data on other meats in order to make comparisons and obtain better conclusions.

\section{Conclusions}

In summary, we can conclude that there are differences between households with and without children under 18 years old in the consumption and purchase habits of turkey and chicken meat. Instead, there is no difference in the image of both meats between the total of the sample and the households with children under 18 years old. Thanks to the analysis of the image, we see that both meats are perceived as healthy and wholesome, but chicken is related to more practical uses. The results of the research can be used to develop appropriate social responsibility strategies in the companies or in the sector based on 3 axes: a) Promoting the meat with a poorer image compared to the other, as both are healthy; b) Encourage children's consumption of both meats; c) Promote a healthy lifestyle among children. These strategies can be carried out through the development of functional and convenience products adapted to the child population and facilitating meal preparation, as well as the development of appropriate communication strategies.

\section{Funding}

This work was supported by the Autonomous Government of the Valencian Region (Spain) under Grant [AICO/2017/066] (Project "Sustainability of the Food Value Chain: From Production to Responsible Consumption").

\section{Contribution}

Conception and design of the work: A. B.-P.; Acquisition of data: L. M.-V.; Analysis and interpretation of data: C. E.-P.; Drafting the article: A. B.-P.; Revising the article: L. M.-V. and C. E.-P.

\section{Disclosure statement}

Authors do not have any competing financial, professional, or personal interests from other parties.

\section{References}

Agrawal, R. (2005). Probiotics: An emerging food supplement with health benefits. Food Biotechnology, 19(3), 227-246. https://doi.org/10.1080/08905430500316474

Arihara, K. (2006). Strategies for designing novel functional meat products. Meat Science, 74(1), 219-229. https://doi.org/10.1016/j.meatsci.2006.04.028

Buckley, M., Cowan, C., \& McCarthy, M. (2007). The convenience food market in Great Britain: Convenience food lifestyle (CFL) segments. Appetite, 49(3), 600-617. https://doi.org/10.1016/j.appet.2007.03.226

Buitrago-Vera, J., Escribá-Pérez, C., Baviera-Puig, A., \& Montero-Vicente, L. (2016). Consumer segmentation based on food-related lifestyles and analysis of rabbit meat consumption. World Rabbit Science, 24(3), 169-182. https://doi.org/10.4995/wrs.2016.4229

Burnier, P. C., Guerra, D. de S., \& Spers, E. E. (2020). Measuring consumer perceptions over beef good practices and sustainable production process. British Food Journal, 123(4), 1362-1383. https://doi.org/10.1108/BFJ-12-2019-0904

Cea, M. A. (2010). Métodos de Encuesta. Teoría y Práctica, Errores y Mejora. Síntesis, S.A.

Cofnas, N. (2019). Is vegetarianism healthy for children? Critical Reviews in Food Science and Nutrition, 59(13), $2052-2060$. https://doi.org/10.1080/10408398.2018.1437024

Cooke, L. J., \& Wardle, J. (2005). Age and gender differences in children's food preferences. British Journal of Nutrition, 93(5), 741-746. https://doi.org/10.1079/BJN20051389

Dalle Zotte, A. (2002). Perception of rabbit meat quality and major factors influencing the rabbit carcass and meat quality. Livestock Production Science, 75(1), 11-32. https://doi.org/10.1016/S0301-6226(01)00308-6

de Olde, E. M., \& Valentinov, V. (2019). The moral complexity of agriculture: a challenge for corporate social responsibility. Journal of Agricultural and Environmental Ethics, 32(3), 413-430. https://doi.org/10.1007/s10806-019-09782-3

Escriba-Perez, C., Baviera-Puig, A., Buitrago-Vera, J., \& Montero-Vicente, L. (2017). Consumer profile analysis for different types of meat in Spain. Meat Science, 129, 120-126. https://doi.org/10.1016/j.meatsci.2017.02.015 
Escribá-Pérez, C., Baviera-Puig, A., Montero-Vicente, L., \& Buitrago-Vera, J. (2019). Children's consumption of rabbit meat. World Rabbit Science, 27(3), 113-122. https://doi.org/10.4995/wrs.2019.11991

Font-i-Furnols, M., \& Guerrero, L. (2014). Consumer preference, behavior and perception about meat and meat products: An overview. Meat Science, 98(3), 361-371. https://doi.org/10.1016/j.meatsci.2014.06.025

Grunert, K. G., Bredahl, L., \& Brunsø, K. (2004). Consumer perception of meat quality and implications for product development in the meat sector - A review. Meat Science, 66(2), 259-272. https://doi.org/10.1016/S0309-1740(03)00130-X

Ilicic, J., Baxter, S. M., \& Kulczynski, A. (2018). To meet or meat? Homophones in advertising encourage judgments and behaviors in children. Journal of Advertising, 47(4), 378-394. https://doi.org/10.1080/00913367.2018.1539361

Maloni, M. J., \& Brown, M. E. (2006). Corporate social responsibility in the supply chain: An application in the food industry. Journal of Business Ethics, 68(1), 35-52. https://doi.org/10.1007/s10551-006-9038-0

Martini, S., Conte, A., \& Tagliazucchi, D. (2019). Comparative peptidomic profile and bioactivities of cooked beef, pork, chicken and turkey meat after in vitro gastro-intestinal digestion. Journal of Proteomics, 208, 103500. https://doi.org/10.1016/j.jprot.2019.103500

McWilliams, A., \& Siegel, D. (2000). Corporate social responsibility and financial performance: correlation or misspecification? Strategic Management Journal, 21(5), 603-609. https://doi.org/10.1002/(SICI)1097-0266(200005)21:5<603::AID-SMJ101>3.0.CO;2-3

Montero-Vicente, L., Escribá-Pérez, C., Baviera-Puig, A., \& Buitrago-Vera, J. (2018). Analysis of the commercial value of rabbit meat based on positioning of the different types of fresh meat. Spanish Journal of Agricultural Research, 16(3), e0110. https://doi.org/10.5424/sjar/2018163-13407

Montero, L., \& Baquero, M. (2016). Análisis del comportamiento de conejas madres en sistemas de cria colectiva mediante redes sociales. Estudio exploratorio - Dialnet. Boletín de Cunicultura Lagomorpha, 182, 36-41.

Pereira, P. M. de C. C., \& Vicente, A. F. dos R. B. (2013). Meat nutritional composition and nutritive role in the human diet. Meat Science, 93(3), 586-592. https://doi.org/10.1016/j.meatsci.2012.09.018

Petraci, M., \& Cavani, C. (2013). Rabbit meat processing: Historical perspective to future directions. World Rabbit Science, 21(4), 217-226. https://doi.org/10.4995/wrs.2013.1329

Reis, G. G., \& Molento, C. F. M. (2020). Emerging market multinationals and international corporate social responsibility standards: bringing animals to the fore. Journal of Business Ethics, 166(2), 351-368. https://doi.org/10.1007/s10551-019-04144-5

Tang, M., Hendricks, A. E., \& Krebs, N. F. (2018). A meat- or dairy-based complementary diet leads to distinct growth patterns in formula-fed infants: a randomized controlled trial. The American Journal of Clinical Nutrition, 107(5), 734-742. https://doi.org/10.1093/ajcn/nqy038 